\title{
Physical, Psychosocial, Occupational Problems and Protection Behaviors Experienced by Pre-Hospital Emergency Healthcare Professionals During The COVID-19 Pandemic
}

\author{
Hastane Öncesi Acil Sağlık Çalışanlarının COVID-19 Pandemi sürecinde \\ Yaşadığı Fiziksel, Psikososyal, Mesleki Sorunlar ve Korunma Davranışları
}

\author{
Mehmet Doğan' \\ 'Erciyes University Health Services Vocational School, Kayseri, Turkey
}

\begin{abstract}
Aim: COVID-19 pandemic has become one of the most critical health problems of the 21 st century. Healthcare workers undoubtedly fulfil the most crucial task of combating this critical health problem all over the world. This study was carried out to determine the experiences of pre-hospital emergency healthcare workers during the COVID-19 process.

Material and Method: This descriptive and cross-sectional study was conducted on 204 healthcare workers working in Kayseri province, Turkey's pre-hospital emergency health services.

Results: $50.5 \%$ of the participants were women, $69.1 \%$ were married, and the average age was $31.7 \pm 5.8$. Of the participants $45.6 \%$ were working as an Emergency Medical Technician, and $85.8 \%$ were university graduates. Of the participants $99.0 \%$ stated that the workload had increased during the COVID-19 process. Of the participants $42.2 \%$ had a coronavirus test and $27.9 \%$ of those who had the test had a positive test result. During the COVID-19 process, $14.7 \%$ of participants were separated from their families, which adversely affected $90.0 \%$ psychologically. While it appears that the participants used personal protective equipment during the COVID-19 process, this increase was $98.5 \%$ in wearing a mask. Of the participants $70.6 \%$ stated an increase in violence against healthcare workers during the COVID-19 process, and $63.7 \%$ of them indicated that they experienced violence during this period.

Conclusions: During the COVID-19 process, the workload of prehospital emergency healthcare workers increased. As a society, support should be given to the combat against the pandemic by following precautions and to healthcare workers due to their devoted work.
\end{abstract}

Keywords: COVID-19, emergency, healthcare workers, pre-hospital
Öz

Amaç: COVID-19 pandemisi 21. yy. en önemli sağlık sorunlarından biri haline gelmiştir. Dünyanın her yerinde bu önemli sağlık sorunuyla ile mücadele en önemli görevi hiç şüphesiz sağlık çalışanları yerine getirmektedir. Bu çalışma, COVID-19 sürecinde hastane öncesi acil sağlık çalışanlarının yaşadıklarıı belirlemek amacıyla yapıımıştır.

Gereç ve Yöntem: Tanımlayıcı ve kesitsel tipteki bu çalıșma Türkiye'de (Kayseri ilinde) hastane öncesi acil sağlık hizmetlerinde görev yapan 204 sağ ık çalışanında yapılmıştır.

Bulgular: Katılımcıların \%50,5'i kadın, \%69, 1'i evli olup yaş ortalaması $31.7 \pm 5.8$ 'dir. \%45,6'sı ATT olarak görev yapmakta olup \%85,8'i üniversite mezunudur. Katılımcıların \%99,0'u COVID-19 sürecinde iş yükünün arttığını ifade etmektedir. Katılımcıların \%42,2'si COVID-19 testi yaptırmış ve test yaptıranların da \%27,9'unun test sonucu pozitiftir. COVID-19 sürecinde katılımcıların \%14,7'si ailesinden ayrı kalmıştır. Aileden ayrı kalanların \%90,0'ının psikolojisi olumsuz etkilemiştir. Katılımcıların COVID-19 sürecinde kişisel koruyucu ekipman kullanımında artış olduğu görünürken; bu artı̧ \%98,5 ile fazla en maske takmada olmuştur. Katılımcıların \%70,6'sı COVID-19 sürecinde sağlık çalışanlarına yönelik şiddet olaylarında artış olduğunu ifade ederken \%63,7'si bu süreçte şiddete uğradığını ifade etmiştir.

Sonuç: COVID-19 sürecinde hastane öncesi acil sağlık çalışanlarııın iş yükü artmışır. Toplum olarak bireysel önlemlere uyarak pandemiyle mücadeleye ve özverili çalışmalarından dolayı sağlık çalışanlara destek olunmalıdır.

Anahtar Kelimeler: COVID-19, acil, sağlık çalışanları, hastane öncesi 


\section{INTRODUCTION}

The coronavirus epidemic, which started with cases of pneumonia with unknown cause, was defined as a new coronavirus (2019-nCoV) that was not detected in humans on January 7, 2020. ${ }^{[1]}$ As in this epidemic; SARS (Severe Acute Respiratory Syndrome), which emerged in China in 2003, and MERS (Middle East Respiratory Syndrome), which emerged in Saudi Arabia in 2012, are also from the coronavirus family. $[2,3]$ The virus was named first as SARS-CoV-2 and then as "COVID-19" due to its close similarity to SARS CoV.[4] The World Health Organization (WHO) classified the COVID-19 outbreak as an "international public health emergency" on January 30 and defined it as a global epidemic (pandemic) on March 11. Although COVID-19 is transmitted through the main droplet, it is transmitted by the droplets emitted by sick individuals by coughing, sneezing, and then touching the mucous membranes of the mouth, nose, or eyes. The virus's common symptoms, which have an incubation period of 2-14 days, include respiratory symptoms, fever, cough and dyspnea. ${ }^{[1]}$

The COVID-19 pandemic, which is spreading rapidly around the world, continues to increase day by day. As of October 29, 2020, it caused 44.5 million cases and 1 million 174 thousand deaths worldwide. Similarly, the number of cases and deaths continues to rise in Turkey. The first case was seen in Turkey on March 11, 2020. Since then, 366 thousand cases and 9 thousand 950 deaths have occurred. ${ }^{[5]}$

Pre-hospital emergency medical services (PEMS) in Turkey fulfills the first professional health services. PEMS in Turkey is implementing the Anglo-American model. ${ }^{[6]}$ PEMS; it is an intervention chain that includes providing emergency care support at the scene to individuals who need urgent assistance due to disaster, accident, or illness and transporting them to the hospital safely. ${ }^{[7]}$ The life-saving medical treatment and care initiated in the field continue during the transport, and the patient is delivered to the hospital emergency services for advanced emergency care. The services' main purpose is to reduce morbidity and mortality, mainly due to major trauma, chronic diseases, and acute health problems. ${ }^{[8]}$

PEMS provides routine health care services. In addition to these services, since mid-March 2020, COVID-19 suspect or positive cases have been intervened in the field and transferred to hospital emergency services. This study was conducted to determine pre-hospital emergency healthcare workers' experiences in approximately eight months since the first COVID-19 case was seen in Turkey.

\section{MATERIAL AND METHOD}

This descriptive and cross-sectional study was conducted during 1 September-20 October 2020 with healthcare professionals working in PEMS in Kayseri province, Turkey. The sample size was not selected in the study, and the whole population was included. At the end of the study, the data of 204 pre-hospital emergency healthcare workers (PEHW) were included. For the study, the ethics committee approval was obtained from the Scientific Research and Publication Ethics Board of Cappadocia
University (Decision Number: 2020.31) and approved by the Ministry of Health Scientific Research Evaluation Commission. A questionnaire consisting of 40 questions related to socio-demographic characteristics, working life, working conditions, and COVID-19 of the participants was prepared. The questionnaire form prepared to eliminate the situations that would negatively affect the pre-hospital emergency healthcare workers' working conditions and the voluntary participation in the study and consider the epidemic's contagion characteristics; A link was created by transferring it to the computer environment. Information about the study was given to the volunteers on the online questionnaire page. The volunteers' informed consent was obtained by choosing the "I agree to voluntarily participate in the study" option on the same page. The data were evaluated with SPSS 15.0 (Chicago, IL, USA) software, percentage and frequency distributions, mean and standard deviation and statistical analysis.

\section{RESULTS}

$50.5 \%$ of PEHW were women and $69.1 \%$ were married. $50.5 \%$ were in the 26-35 age group, and the average age was $31.7 \pm$ 5.8. 45.6\% worked as an Emergency Medical Technician (EMT) and $41.7 \%$ as a paramedic. $48.5 \%$ of the PEHW had worked for $10-20$ years. While $11.3 \%$ had a chronic disease, the most common chronic disease was asthma, with $17.4 \%$.

In the COVID-19 process, $99.0 \%$ of the PEHW stated that their workload increased, $97.1 \%$ did not see the necessary value. While $42.2 \%$ of the PEHW had the COVID-19 test, $27.9 \%$ had a positive test result. $87.7 \%$ of PEHW stated that their psychology was affected due to the possibility of being COVID-19 positive and infecting their family. During the COVID-19 process, $85.3 \%$ of PEHW continued to stay with their families, $8.3 \%$ rented another house, $3.9 \%$ sent their family to relatives and $2.5 \%$ stayed in a hotel/dormitory. The evaluation of PEHW according to some characteristics during the COVID-19 process is shown in Table 1.

During the COVID-19 process, the habit of wearing masks had an increased rate of $98.5 \%$ of PEHW. With an increasing rate of $77.5 \%$, wearing gloves was the lowest increase in personal protective equipment (PPE). There was an increase in hand disinfectant use by $96.6 \%$, protective gown with $92.6 \%$, handwashing with $89.7 \%$, and goggle /face shield with $85.3 \%$. The change in the habit of hand-washing and the use of PPE by PEHW during the COVID-19 process is shown in Table 2.

$63.7 \%$ of PEHW were exposed to violence during the COVID-19 process. $63.2 \%$ of those who stated that they experienced a violent incident experienced verbal assault/insult, 9.3\% physical violence/injury. While $73.0 \%$ of them notified about the violence experienced, most notifications were made by searching for the white code. They stated that the most violence was done by the relatives of the patients (99.0\%) and the reason for using violence was the lack of education/seeing violence as a method of seeking justice with $65.2 \%$. The evaluation of the violent events experienced by PEHW during the COVID-19 process is shown in Table 3. 


\begin{tabular}{lc} 
Table 2. Changes in pre-hospital emergency health care workers' handwashing habits and personal protective equipment usage during the COVID-19 process \\
\hline
\end{tabular}

Table 1. Evaluation of pre-hospital emergency healthcare workers according to some characteristics of the COVID-19 process

\begin{tabular}{lcc} 
& $\mathbf{n}$ & $\%$ \\
\hline $\begin{array}{l}\text { Did you increase your workload in the COVID-19 process? } \\
\text { Yes }\end{array}$ & 202 & 99,0 \\
No & 2 & 1,0 \\
Did you see the necessary value in the COVID-19 process? & 6 & 2,9 \\
$\quad$ Yes & 198 & 97,1 \\
$\quad$ No & & \\
Did you take a COVID-19 test? & 86 & 42,2 \\
Yes & 118 & 57,8 \\
No & & \\
COVID-19 test result (n=86) & 62 & 72,1 \\
$\quad$ Negative (-) & 24 & 27,9 \\
Positive (+) & & \\
Are anyone of your colleagues positive (+) for COVID-19? & 153 & 75,0 \\
$\quad$ Yes & 51 & 25,0 \\
$\quad$ No & & \\
Is anyone in your family positive (+) for COVID-19? & 36 & 17,6 \\
$\quad$ Yes & 168 & 82,4
\end{tabular}

Did the possibility of being COVID-19 and infecting your family affect your psychology?

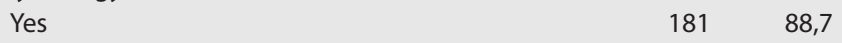

$\begin{array}{lll}\text { No } & 23 & 11,3\end{array}$

Where did you stay during the COVID-19 process?

Continued to stay in the same house with the family $174 \quad 85,3$

$\begin{array}{llll}\text { Rented another house } & 17 & 8,3\end{array}$

$\begin{array}{lll}\text { Sent the family to relatives } & 8 & 3,9\end{array}$

Hotel/ dormitory $\quad 5 \quad 2,5$

Did your separation from the family affect your psychology? $(n=30)$

$\begin{array}{lrr}\text { Yes } & 27 & 90,0\end{array}$

No 310,0

Did you receive psychological support during the COVID-19 process?

Yes $\quad 4 \quad 2,0$

No

Did you have trouble finding personal protective equipment during the COVID-19 process?

$\begin{array}{lcc}\text { Yes } & 19 & 9,3 \\ \text { No } & 111 & 54,4 \\ \text { Sometimes } & 74 & 36,3 \\ \text { Has your sleep pattern been affected during COVID-19? } & & \\ \text { Yes } & 154 & 75,5 \\ \text { No } & 21 & 10,3 \\ \text { Sometimes } & 29 & 14,2\end{array}$

\section{DISCUSSION}

Healthcare professionals are at significant risk for COVID-19 due to the nature of their work. COVID-19; healthcare workers in most countries of the world have become infected and died. ${ }^{[9]}$ Although WHO has not published a systematic report on COVID-19 cases and deaths by healthcare professionals, according to the 82 Situation Report dated April 11, 2020, a total of 22 thousand 73 COVID-19 cases have been reported in 52 countries. ${ }^{[10]}$ In the report titled "Epidemiological Alert COVID-19 Among Healthcare Workers," published on August 31, 2020, by the Pan American Health Organization (PAHO), approximately 570 thousand cases of COVID-19 and 2 thousand 506 deaths occurred among healthcare workers in the PAHO region. ${ }^{[1]]}$ In a study conducted at the Los Angeles County Department of Public Health, 5,500 healthcare workers were diagnosed with COVID-19. EMT/paramedics constituted $1.2 \%(61)$ of the diagnosed healthcare workers. ${ }^{[9]}$ There is no official explanation of COVID-19 cases and deaths by healthcare workers in Turkey. According to the report of the Turkish Medical Association (TMA) dated April 1, 3474, healthcare workers have been infected with COVID-19 in Turkey. ${ }^{[12]}$ In a review of Turkish studies until September 12, 85 health workers have died due to the COVID-19. 4.7\% (4) of the deceased healthcare workers are PEHW. ${ }^{[13]}$ In our study, $11.8 \%$ of PEHW were COVID-19 (Table 1). Although there are differences in our study results, $\mathrm{WHO}$ reports, and individual studies, healthcare workers worldwide become infected and die due to COVID-19. Also, healthcare workers being infected with COVID-19 does not only affect themselves. It also poses a risk for colleagues, family, and patients. In our study, $75.0 \%$ of the pre-hospital emergency healthcare workers' colleagues and $17.6 \%$ of their families were positive for COVID-19 tests (Table 1).

Since healthcare workers are faced with infection in the fight against COVID-19, the most important way for healthcare workers to protect themselves is through PPE and hand hygiene. ${ }^{[14]}$ All healthcare workers involved in combating COVID-19 require adequate PPE to protect their health. ${ }^{[15]}$ 


\begin{tabular}{|c|c|c|}
\hline & $\mathbf{n}$ & $\%$ \\
\hline \multicolumn{3}{|l|}{ Did you observe an increase in violence against health workers during the COVID-19 process? } \\
\hline Yes & 144 & 70,6 \\
\hline No & 60 & 29,4 \\
\hline \multicolumn{3}{|l|}{ Did you experience any violence during the COVID-19 process? } \\
\hline Yes & 130 & 63,7 \\
\hline No & 74 & 36,3 \\
\hline \multicolumn{3}{|l|}{ What violence happened during the COVID-19 process? * } \\
\hline Verbal assault /insult & 129 & 63,2 \\
\hline Physical violence /injury & 19 & 9,3 \\
\hline Sexual violence & 1 & 0,5 \\
\hline \multicolumn{3}{|l|}{ Who was violent? * } \\
\hline Patients' relatives & 202 & 99,0 \\
\hline People on the scene & 88 & 43,1 \\
\hline Patients & 53 & 26,0 \\
\hline \multicolumn{3}{|l|}{ What was done about the violence? $(n=159)$} \\
\hline Notification made & 116 & 73,0 \\
\hline No notification made & 43 & 27,0 \\
\hline \multicolumn{3}{|l|}{ Where were the incidents of violence reported? ${ }^{*}$} \\
\hline Code white searched & 92 & 45,1 \\
\hline Chief Physician / Health Directorate & 55 & 27,0 \\
\hline Police/ Prosecutor's Office & 40 & 19,6 \\
\hline \multicolumn{3}{|l|}{ What are the causes of violence against healthcare professionals? ${ }^{*}$} \\
\hline Lack of education for those who use violence / Seeing violence as a way to seek justice & 133 & 65,2 \\
\hline Inciting violence in the media (especially with anti-health worker provocative publications) & 128 & 62,7 \\
\hline The perception that healthcare professionals earn a lot of money & 120 & 58,8 \\
\hline Dissatisfaction with the treatment / High level of expectation & 109 & 53,4 \\
\hline Desire to attract attention / Psychological problems due to the thoughts of neglect & 107 & 52,5 \\
\hline The belief that the ambulance arrived late at the scene & 104 & 51,0 \\
\hline Getting bad news about the patient's condition / Blame the healthcare professionals & 103 & 50,5 \\
\hline Being under the influence of alcohol and drugs-substance abuse & 93 & 45,6 \\
\hline Negative attitudes and behavior of healthcare professionals & 37 & 18,1 \\
\hline \multicolumn{3}{|l|}{ Did you consider working in another profession or other health field due to violence? } \\
\hline No & 41 & 20,1 \\
\hline I thought about changing to another profession & 140 & 68,6 \\
\hline I thought of moving to another healthcare field & 23 & 11,3 \\
\hline
\end{tabular}

Especially PEHW may be exposed to COVID-19 due to patient contact or contaminated environments. ${ }^{[16]}$ In our study, 54.4\% of the PEHW stated that they did not have trouble finding PPE, and $45.6 \%$ (36.3\% sometimes) stated that they could not find PPE in the early stages, but they have not experience such a problem throughout the working period (Table 1). Mask [Medical-Respirator (N95, FFP2)], gloves, gown, goggle, and face shield are the PPE of healthcare workers. ${ }^{[16]}$ In the report named "COVID-19 Recommendations: Prehospital Emergency Medical Services" published by PAHO, PEHW stated which personal equipment will be used in which situations. In the report; "suspected case of COVID-19 1-meter assessment (ambulance crew)" recommended hand hygiene and wearing a surgical mask and "suspected or confirmed case of COVID-19 requiring medical transport and with aerosol-generating procedure" recommended hand hygiene, respirator mask, apron, gloves, glasses and face protection. ${ }^{[16]}$ In our study, it is seen that there is an increase in healthcare workers related to the use of all PPE. During the COVID-19 process, the highest increase was observed in masks with $96.6 \%$, the use of a protective gown with $92.2 \%$, and protective goggle/face shield with $85.3 \%$.
Hand-washing habits increased by $89.7 \%$ (Table 2). Our study results, similar to a study conducted in Japan, masks became the most frequently used PPE. ${ }^{[17]}$ In all countries to combat COVID-19, healthcare workers should have no trouble finding PPE. Healthcare professionals should be careful in using PPE. In this way, healthcare professionals will protect their health and their patients, colleagues, and families.

Any event or situation where a person is abused, threatened, or attacked in the workplace is considered "workplace violence."[18] Although violence is observed in all work environments healthcare workers are more exposed to violence in the workplace. ${ }^{[19]}$ The risk of being exposed to violence in healthcare workers is 16 times higher than in other service sector occupational groups. ${ }^{[20]}$ A systematic literature review shows that $70-80 \%$ of emergency health care workers have experienced one or more violence cases. [21] In Turkey (in Ankara), on the statistical analysis of applied violence to health workers, $13.1 \%$ of violence cases occurred in PEHW. ${ }^{[22]}$ In another study in Turkey (in İstanbul), 39.8\% of PEHW have been exposed to physical violence and $94.9 \%$ to verbal violence. ${ }^{[23]}$ In our study, $63.7 \%$ of PEHW were exposed 
to violence during the COVID-19 process. Those exposed to violence; $63.2 \%$ have been subjected to verbal assault/insult, $9.3 \%$ to physical violence/injury. According to PEHW, "the lack of education-seeing violence as a means of seeking justice" is seen as the most common cause of violence with $65.2 \%$ (Table 3). Our study findings are similar to the prevalence of violence exposed by pre-hospital emergency healthcare workers. The prevalence of violence, which ranged between $61 .-78.1 \%$ in the studies performed, was found to be $63.7 \%$ in our study. [24-27]

\section{CONCLUSIONS}

During the COVID-19 process, the workload of PEHW has increased. During this period, two out of approximately three PEHW were exposed to violence. Among PEHW, there have been those diagnosed with COVID-19. These days when we are experiencing the COVID-19 process, the increasing workload, COVID-19 cases among healthcare workers and their exposure to violence may become a problem in the future for all healthcare workers, especially PEHW. A problem that may arise can also cause trouble in terms of combating COVID-19. To correct these situations, all healthcare professionals should be valued, and their rights should be respected. COVID-19 tests should be performed routinely for all healthcare professionals. Deterrent legal arrangements should be made to prevent violence against healthcare workers. All positive developments for the healthcare worker will result in positive developments in terms of the COVID-19 outbreak.

\section{ETHICAL DECLARATIONS}

Ethics Committee Approval: For the study, the ethics committee approval was obtained from the Scientific Research and Publication Ethics Board of Cappadocia University (Decision Number: 2020.31).

Informed Consent: All patients signed the free and informed consent form.

Referee Evaluation Process: Externally peer-reviewed.

Conflict of Interest Statement: The authors have no conflicts of interest to declare.

Financial Disclosure: The authors declared that this study has received no financial support.

Author Contributions: All of the authors declare that they have all participated in the design, execution, and analysis of the paper, and that they have approved the final version.

\section{REFERENCES}

1. COVID-19 (SARS-CoV2 Infection) Guide (Science Committee Work) (2020). T.C. Ministry of Health, 29 June 2020, Ankara, 1-29. https://covid19.saglik. gov.tr/Eklenti/39060/0/covid-19rehberigenelbilgilerepidemiyolojivetani pdf.pdf. Published 2020. Accessed October 29, 2020.

2. World Health Organization. Summary table of SARS cases by country, 1 November 2002 -7 August 2003. http://www.who.int/csr/sars/ country/2003_08_15/en/index.html. Accessed October 29, 2020.
3. Zaki AM, van Boheemen S, Bestebroer TM, Osterhaus ADME, Fouchier RAM. Isolation of a novel coronavirus from a man with pneumonia in Saudi Arabia. N Engl J Med 2012;367:1814-20.

4. World Health Organization, Coronavirus disease 2019 (COVID-19) Situation Report-7.https://www.who.int/docs/defaultsource/ coronaviruse/situationreports/2020022. Published 2020. Accessed October 29, 2020.

5. World Health Organization, WHO Coronavirus Disease (COVID-19) Dashboard. https://covid19.who.int/. Published 2020. Accessed October 29, 2020.

6. Dick WF. Anglo-American vs. Franco-German emergency medical services system. Prehosp Disaster Med 2003;18(1):29-37.

7. Doğan M, Şenol V, Çetinkaya F, Naçar M, Bülbül E. Knowledge, Consideration and Satisfaction Level of People in Kayseri Province About The 112 Emergency Health Services. J Contemp Med 2020;10(3):415-20.

8. Doğan M. Paramedic. In: Doğan M, ed, Occupational Health and Safety in Emergency Healthcare Services, Ankara, Turkey: 23-30.

9. Hartmann S, Rubin Z, Sato H, Yong KO, Terashita D, Balter S. Coronavirus Disease 2019 (COVID-19) Infections Among Healthcare Workers, Los Angeles County, February-May 2020. Clin Infect Dis. DOI: 10.1093/cid/ ciaa1200.

10. World Health Organization, Coronavirus disease 2019 (COVID-19) Situation Report - 82. https://www.who.int/docs/default-source/ coronaviruse/situation-reports/20200411-sitrep-82-covid-19. pdf?sfvrsn=74a5d15_2. Published 2020. Accessed October 29, 2020.

11. Pan American Health Organization. Epidemiological Alert COVID-19 Among Healthcare Workers 31 August 2020. https://www.paho.org/en/ documents/epidemiological-alert-covid-19-among-health-workers-31august-2020. Published 2020. Accessed November 1, 2020.

12. Turkish Medical Association. Press Briefing, Number of Turkey in Covidien-19 Increasing Health Care Workers Who were Diagnosed. https://www.ttb.org.tr/kollar/userfiles/files/ttbcovid-saglikcalisanlari_-EN-SON.pdf. Published 2020. Accessed October 29, 2020.

13. Saatçı E. COVID-19 Pandemic and health professionals: Keep them alive or survive? Türk Aile Hek Derg 2020;24(3):153-66. doi: 10.15511/ tahd.20.00353.

14. World Health Organization, Rational use of personal protective equipment for coronavirus disease (COVID-19) and considerations during severe shortages. https://apps.who.int/iris/bitstream/ handle/10665/331695/WHO-2019-nCov-IPC_PPE_use-2020.3-eng. pdf?ua=1. Published 2020. Accessed October 29, 2020.

15. Papoutsi E, Giannakoulis VG, Ntella V, Pappa S, Katsaounou P. Global burden of COVID-19 pandemic on healthcare workers. ERJ Open Res. 2020; 6: 00195-2020.

16. Pan American Health Organization. COVID-19 Recommendations: Prehospital Emergency Medical Services (EMS). https://iris.paho.org/ bitstream/handle/10665.2/52137/PAHOPHEIHMCOVID-19200014_eng. pdf? sequence=1\&isAllowed=y. Published 2020. Accessed November 1, 2020.

17. Unoki T, Tamoto M, Ouchi A, et al. Personal protective equipment use by health-care workers in intensive care units during the COVID-19 pandemic in Japan: comparative analysis with the PPE-SAFE survey. Acute Med Surg 2020;7:e584. doi: 10.1002/ams2.584

18. Holleran RS, Mars TS. "Preventing staff injuries from violence," J Emerg Nurs 2006;32(6):523-4.

19. Hahn S, Zeller A, Needham I, Kok G, Dassen T, Halfens RJG. Patient and visitor violence in general hospitals: a systematic review of the literature. Aggression and Violent Behavior, 2008; 13(6):431-441.

20. Kingma M. Workplace violence in the health sector: a problem of epidemic proportion. Int Nurs Rev 2001;48:129-130.

21. Pourshaikhian M, Gorji HA, Aryankhesal A, Khorasani-Zavareh D, Barati A. Systematic literature review: workplace violence against emergency medical services personnel. Arch Trauma Res 2016;5(1):1-14. 
22. Yıldız MS. Violence against healthcare professionals in turkey: a research in Ankara. Hacettepe Journal of Health Administration, 2019; 22(1): 135156.

23. Gülen B, Serinken M, Hatipoğlu C, Özaşır D, Sönmez E, Kaya G, Akpınar G. Work-related injuries sustained by emergency medical technicians and paramedics in Turkey, Turkish Journal of Trauma and Emergency Surgery. 2016;22(2):145-149.

24. Alharthy N, Mutairi MA, Alsahli A, et al., Workplace violence among emergency medical services workers in Riyadh, Saudi Arabia. Journal of Hospital Administration, 2017; 32(6):26-32.

25. Gormley MA, Crowe RP, Bentley MA, et al., A national description of violence toward emergency medical services personnel. Prehospital Emergency Care, 2016;20(4):439-447.

26. Lindquist B, Koval K, Mahadevan A, et al. Workplace violence among prehospital care providers in India: a crosssectional study. BMJ Open 2019;9:e033404. doi:10.1136/bmjopen-2019-033404

27. Hosseinikia SH, Zarei S, Kalyani MN, Tahamtan S. A Cross-Sectional Multicenter Study of Workplace Violence against Prehospital Emergency Medical Technicians. Emerg Med Int 2018: 1-5. https://doi. org/10.1155/2018/7835676 